\title{
Food sustainability, healthy eating, on-trend diets: media representations of nutrition in Romania and Germany
}

\author{
Valentina Marinescu ${ }^{1}$, Simona Rodat ${ }^{2 *}$ \\ ${ }^{1}$ University of Bucharest, Faculty of Sociology and Social Work, Bd. Schitu Măgureanu nr. 9, Sector 1, 010181 Bucharest, Romania \\ 2 Adventus University, Faculty of Theology and Social Sciences, Şos. Decebal nr. 11-13, 077035 Cernica, Ilfov, Romania
}

\section{KEYWORDS}

Food

Germany

Media coverage

Nutrition

Romania

\begin{abstract}
The importance of nutrition as a research topic is linked not only to healthy eating and different types of medical conditions, such as obesity, allergies, malnutrition, but also to the relationship between nutrition and physical activity, to state's and large food companies' commercial activities, as well as to the sustainability of food production. On that basis, numerous studies have analyzed media content related to food and nutrition, their basic assumption being that (new and old) media have the ability to change the audience's perceptions, behaviors and attitudes towards various values which are accepted in contemporary societies. This paper presents the results of a comparative study of the way in which Romanian and German media cover the topic of nutrition. The research method used was the content analysis, applied to a sample of articles published on online media from the two countries between 2014 and 2016. Having as research objective the identification of the most relevant aspects regarding the content and shape of nutrition's coverage in media, this article discusses the similarities and differences recorded in the online press of the two countries on the topic of interest. According to the findings, the similarities are mainly related to some topics and subjects addressed, as well as to the ways of covering them, in particular through analysis articles, while the differences could instead be ascertained regarding the content of the articles, including the ways in which the journalists assume social roles in approaching, informing, debating, and educating concerning issues of public interest.
\end{abstract}

\footnotetext{
* Contact address: simona.rodat@uadventus.ro (S. Rodat)
} 


\section{Introduction}

Nutrition is an activity that regularly and constantly affect people's lives and has an impact at the personal and emotional levels. Food and nutrition are vital for people and require daily recurrent individual and collective actions that involve decisions, planning and organization. At the social level, nutrition is associated not only with values (permissiveness, thriftiness, allowability, etc.), social interactions and work, but also with well-being, prosperity, enjoyment and fun. Nutrition is also strongly connected with health, which is another general concern for individuals.

Therefore, such topics of interest have been constantly addressed by the media. In recent years, media interest on nutrition and health became more diverse, new themes emerged among the topics, such as health food, current dietetic trends, sustainable nutrition, balanced lifestyles, risks related to the consumption of certain foods, or the impact of human nutrition (especially the food industry, agriculture and animal husbandry) on the environment.

The present paper presents some of the results of a comparative analysis of food and nutrition media coverage in Romania and Germany. The study involved a quantitative and qualitative thematic content analysis (Krippendorff 2018; Anderson 2007; Vaismoradi, Turunen and Bondas 2013). It covered a three years period of time (2014-2016). The sample analyzed was made up of the online media articles that referred to the topics of nutrition and food, and were published in the two countries in the above-mentioned time frame.

In our study we were interested, on the one hand, to identify which were the topics of interest for the media related to nutrition and how they were mediatised and, on the other hand, to identify the similarities and differences between the two countries, both in terms of the topics covered and the content of the articles, as well as regarding the aspects of media coverage of nutrition. 


\section{Theoretical framework}

Media plays a key role in informing the public about the evolution of science. In particular, issues related to health are an important part of media communication (Chapman 2001; Scherer and Link 2017), and nutrition has always been among the health risk factors discussed by the media (Coleman, Thorson and Wilkins 2011). A survey made by Kaiser Family Foundation in 2005 showed that $40 \%$ of respondents pointed out the media as the main source of information about health, while only $20 \%$ of them said that this kind of information was obtained from doctors, and $14 \%$ stated that family members and friends are their main sources (The Henry J. Kaiser Family Foundation 2005). Many studies (McIntosh and Blalock 2005; Grilli, Ramsay and Minozzi 2002; Wilkinson and Marmot 2003) underline that the way in which media present health has a peculiar influence on social behaviors. Although in recent years the circulation of newspapers has declined, and the Internet took over, the traditional media (even in electronic format) has still a vital role in setting public health's agenda of the population (Roberts, Wanta and Dzwo 2002; Paulussen and Harder 2014).

Health, food and nutrition are ubiquitous topics in media (Rössler 2006; Benterbusch 1997). In addition to the broadcasts about the connection between nutrition and health, those about cooking, TV shows and gastronomic competitions, food advice, recipes and diets presented in magazines, etc., mass media is currently presenting new formats, such as the programs offering counselling, in form of nutritional tips and information, or even in the form of reality soap operas, where the consequences of the diets or regimens followed by some volunteers, usually overweight people, are displayed. Furthermore, raising awareness for the need of increased sustainability in all areas, has led to the emergence of new media topics, such as local agriculture, organic crops, urban agriculture, etc., including in the form of information campaigns.

Food and nutrition are represented in the media not only in the nonfictional genres, but also in the fictional ones: the food and all the contexts assumed by the feeding process are ubiquitous in films, serials and other 
types of shows or fictional media programs. Unlike the non-fictional media content, which, for the most part, assume a role of information and even education, in fictional programs, some harmful foods and drinks, such as some soft drinks with excessive sugar content, or alcohol, if not presented in a positive way, are at least popularized as such, the result being an enhancement of their consumption. In addition, the advertising and media marketing of food products still remains an important part of food and nutrition coverage. By its own purpose, advertising - including the one made for products with low nutritional value, or for foods and drinks that are known to be harmful for health, such as alcohol, sweets and other high-sugar, high-processed or high-fat foods - praises the products in order to make people buy them, thus encouraging their purchase and consumption, and not discernment, rational behaviour, or attention to health and healthy eating.

At the moment, nutrition and food are generating new forms of media engagement by including them as topics for discussion on social networks, websites for photo sharing and mobile applications. Researchers on nutrition, food and lifestyle fields have identified changes of the way in which media cover these topics. Such changes are mainly the results of the shifts in consumers' interests and engagements, as well as of the development of consumer-oriented food and nutrition policies of a neoliberal nature (Miller 2007; Lewis 2008; Ouellette and Hay 2008). The neoliberal model for trade and agriculture (Wittman 2011; Edelman et al. 2014) lays stress on the globalization and industrialization of agriculture in the quest for increased food security, with the intention of increasing the global production of food (Woods 2012). Food security, the central concept of this vision, refers to the sustained and assured access of all individuals and social groups to adequate food, in the quantity and quality necessary to meet nutritional needs (Edelman 2014).

A great part of the existing literature from the domain has been focused on consumers' personal nutrition and eating habits (de Solier 2005; Johnston and Baumann 2010; Leer and Klitgaard Povlsen 2016; Elmadfa and Leitzmann 2015 ) and on the way in which those are presented and covered by media (Rousseau 2012; Bradley 2016; Lavin 2013). Such studies have considered both 
the new strategies aiming at consumers, which go beyond conventional nutritional systems and are interested in the impact of nutrition and food on health, environment and welfare of animals, and the eating and lifestyle habits involved in purchasing, preparing, consumption, disposal and media coverage of food and nutrition.

At the same time, some researchers have pointed out that some representations of food and nutrition in media contain inaccuracies (Henderson, Kitzinger and Green 2000; Philo et al. 1994) or are incomplete and biased (Stryker 2002). In a review of over 500 health-related news, Schwitzer (2008) found that only $33 \%$ of media outlets have adequately presented the dangers related to nutrition and food, $35 \%$ of them adequately discussed the quality of evidence in connection with those topics and 56\% used some independent sources and exposed conflicts of interest in these domains (Schwitzer 2008). Previous studies have also shown that media coverage of nutrition and food has often been sensationalist, using titles that do not accurately reflect the essence of the covered scientific researches (Bartlett, Sterne and Egger 2002; Basu and Hogard 2008). This journalistic tendency towards sensationalism and scandalization, but also towards negativism (Caple and Bednarek 2013), has been one of the defining features of the phenomenon called "tabloidization" in the media, that is, the drastic change currently noticed in mainstream media news, which involves replacing topics concerning politics and civic issues, with media content designed to attract attention and to entertain, that is, the kind of news that is expected to be found in tabloid publications. Articles written in a tabloid manner tend to emphasize sensational elements, including infamous aspects and/or obscene details, and to use rumours and gossip about celebrities and public figures, as well as a lot of photos of this type, rather than to publish and to discuss issues designed to keep the public informed about government policies and societal topics (Burleson Mackay 2017). This trend includes, for example, the "disclosures" made by the media regarding some supposedly "scandalous" aspects of food and nutrition, such as the spreading of some nutrition-related phenomena or the presentation of some conditions such as bovine spongiform 
encephalopathy (popularly known as "mad cow disease"), avian influenza or African swine fever. These "disclosures" include the use of visual elements that, through emotionalization (Hänsli 2006, 72), are meant to draw attention to them (and subsequently to the media outlets that make them public), as in the examples above, through the mass killing of infested animals.

Moreover, other studies (Nagler 2014; Hackman and Moe 1999; Gross 2009) have shown that in many articles from media, messages about food are often contradictory or contain unbalanced views on health and nutrition. In this regard, the study carried out by Borra, Earl and Hogan (1998) draws attention to the fact that "most news about nutrition have failed to provide contextual information". Therefore, possible inaccuracies and lack of contextualization are the key elements that question the value of media information about food and nutrition, as well as the ability of individuals to interpret and understand health information in ways that help them to improve their health (Sihota and Lennard 2004). However, as some authors (Len-Ríos et al. 2009; Nerlich and Koteyko 2008) draw the attention, the role of media in relation to health, food and nutrition is not to supply the deficiencies of health public services, but only to inform about those topics.

Therefore, nowadays different phenomena, sometimes contradictory and/or paradoxical, can be found regarding the media coverage of food and nutrition. On the one hand, health issues, such as the link between nutrition and health of individuals and the population, are covered in a serious tone, often with concern, by the media, which frequently assumes a well-defined informative and educational role in this case. The information about the nutritional values of foods, the efficiency of some diets, the processes involved in food production and consumption, or new topics on sustainable nutrition, healthy food, animal welfare or environmental damage is heading in the same direction. On the other hand, it cannot be ignored that media is constantly attempting to draw attention at food and beverages, including those recognized as "unhealthy", through a wide range of culinary delights and temptations, especially through advertising, but also through countless fictional and non-fictional programs, in which food and beverages are 
ubiquitous presented. Indeed, these media contents are seen by some researchers (Burkard and Huth 2010; Raisborough 2016), as being among the main causes of the continuous increase in the number of overweight and obese people.

In this context, some studies, made mainly in the USA and less in Europe (Rössler 2006), reflect the media consumption's influence on population health behaviour. Many of these researches are focused, among other things, on identifying the possibilities and limitations of health education through mass media and setting up the efficiency of presenting some topics related to health on television, both in non-fictional and fictional programs.

\section{General considerations on research and the two countries selected for the comparative analysis}

The study presented here is part of a larger comparative research, which included several European countries (Romania, Republic of Moldova, Bulgaria, Poland, Estonia, Germany, UK), and whose general objective was to analyse the way in which media, namely online news, covered the topic of food and nutrition in the period 2014-2016. The purpose of the international project was to provide an overview at European level on the topic, as well as to collect data that allow us to make inferences and comparisons.

As we have found out in our international project, nutrition is a topic often addressed by the media in all countries included in the research, although in different ways. In this paper we have chosen to make a comparison between the media coverage of this theme in two countries members of the European Union - namely Romania, a country in Eastern Europe, in the former Soviet bloc, and Germany, a country in Western Europe. While Germany was one of the six founding countries of the European Union (in 1951, originally the European Coal and Steel Community/ ECSC), Romania became a member of the European Union in 2007. Besides the historical and geographical differences, the two countries also differ in their 
political and administrative system: while Germany is a federal state, decentralized in almost all areas, Romania is a unitary state, in which decisions are made by one government and are disseminated from the centre hierarchically. Differences in terms of centralization and decentralization, respectively, can be noticed also between the health systems in the two countries, systems to which nutrition is closely related. In Germany, the country with the world's oldest national social health insurance system (Carrin and James 2005) and with one of the most restriction-free and consumer-oriented health-care system in Europe (Health Consumer Powerhouse 2016), the federal government and the local governments have virtually no role in the direct delivery of health care, this being delegated to the self-governing associations of the "sickness funds" and the provider associations (The Commonwealth Fund 2013). In Romania, before 1989 a Semashko model of the health system (Doboș 2008) was adopted, the financing and management of this system being completely under the state's control. Even after 1999, when this model of organizing was changed in order to decentralize the system (Vlădescu et al. 2016), there still exist central interferences on the implementation of certain programs at regional/ local level (ibid.), along with the perpetuation of a tradition of under-financing the health system. Thus, while in the European Union in 2017 the average healthcare expenditure relative to GDP was of 9,9\%, in Romania that was only 5,2\% (Eurostat 2020). At the same time, among the EU Member States, Germany had the highest healthcare expenditure relative to GDP in 2017, namely 11,3\% (ibid.), therefore, above the European average and more than double compared to Romania.

Another issue connected with the health and nutrition in a country is the lifespan of the population. In terms of life expectancy at birth there are too significant differences between the two countries: while in Germany the life expectancy at birth was 80,4 years between 2010-2015 and would be 81,1 years between 2015-2020, in Romania the life expectancy at birth was 74,9 years between 2010-2015 and would be 75,8 years between 2015-2020 (United Nations, Department of Economic and Social Affairs 2019). 
As regards media regulation, in Germany, a federal republic consisting of 16 states (Bundesländer), although there is a federal state competence for telecommunications, the competence to ensure the functioning of the media system is in the hands of the states (Schulz et al. 2008, 7). The freedom of expression is expressed as a basic right of communication in Article 5 paragraph 1 of the German Basic Law/ Constitution (Grundgesetz): "Everyone shall have the right to freely express and disseminate one's opinion in form of speech, writing and pictures, and to freely inform oneself by using generally accessible sources. Freedom of press and freedom of reporting by means of broadcast and by using film are guaranteed. There shall be no censorship" (Basic Law for the Federal Republic of Germany, Art. 5). Freedom of expression is also guaranteed in Romania, by Article 30 of the Constitution, which provides, in its first four paragraphs: “(1) Freedom of expression of thoughts, opinions or beliefs and freedom of creation of any kind, by orally, through writing, images, sounds or other means of public communication, are inviolable. (2) Censorship of any kind is prohibited. (3) Freedom of the press also implies the freedom to set up publications. (4) No publication may be suppressed" (Constituția României, Art. 30).

Concerning the freedom of the press in the two countries, according to the World Press Freedom Index in 2020, which takes into consideration both print and digital versions of the press, and regards criteria categories and indicators such as pluralism, media independence, transparency, environment and self-censorship, legislative framework, infrastructure and abuses, in a ranking that takes into account 180 countries, Germany is in $11^{\text {th }}$ place with a score of 12,16 and Romania in $48^{\text {th }}$ place with a score of 25,91 (Reporters without Borders 2020). Ever since the 2013 index, countries have been given scores ranging from 0 to 100, with 0 being the best possible score and 100 the worst (ibid.). Therefore, according to the scores calculated in 2020, both countries are in the first third of the ranking in terms of press freedom, however with Germany placed much better than Romania, with 37 places ahead of it. 
Also, according to the Media Pluralism Monitor (MPM) regarding Romania, the highest risks concerning media pluralism are in the areas of political independence ( $65 \%$ risk) and market plurality (64\% risk). Thus, lack of political independence represents the most significant threat to media pluralism in Romania, with three indicators having a risk level over $80 \%$ : the independence of public sector media governance and funding (92\%), political control over media outlets (88\%), and editorial autonomy (81\%), determined both by the regulatory framework and actual practice, made possible by structural factors such as dysfunction of the media market, high political polarization and weak impartial state institutions (Popescu, Mihai and Marincea 2016). As for the market plurality, commercial and owner influence over editorial content poses a high risk (79\%), partly due to the ineffectiveness of non-binding self-regulatory rules in a context of economic vulnerability of the media sector (ibid.). Other risks are determined by the lack of appropriate sector-specific legislation of concentration of media ownership (72\%), and especially by the cross-media concentration of ownership and competition enforcement (69\%) (ibid.). Besides political independence and market plurality, other areas assessed in order to rate the media pluralism are social inclusiveness (concerned with access to media by various groups in society) and basic protection (which regards the regulatory backbone of the media sector). In these two areas, too, Romania registers medium risks: $54 \%$ for the social inclusiveness and $34 \%$ as regards the basic protection. In the same project of the Media Pluralism Monitor (MPM), using the same measurement scales and indicators, the risks related to media pluralism in Germany are much lower (Schroeder and Dankert 2016): the risk concerning political independence in Germany is only $11 \%$ (as opposed to $65 \%$ in Romania), the risk regarding market plurality is $24 \%$ (while in Romania $64 \%$ is the case), and the risk related to basic protection is $13 \%$ (while in Romania: $34 \%$ ). Only in terms of social inclusiveness in Germany there is a higher average risk, namely $38 \%$, which is, however, lower than the risk in the same area in Romania (54\%). 
Given, on the one hand, these differences of a political nature, of the health system and of varied aspects regarding the media in the two countries, and on the other hand, the interest shared in both states for nutrition, we considered it interesting to carry out a comparative analysis between the two countries in terms of food and nutrition media coverage. Moreover, the authors of this paper were responsible for conducting the national research, in Romania and Germany, within the mentioned international project. This provided us extensive knowledge about the respective national research data, necessary to make further comparisons and inferences regarding the media coverage of nutrition in the two countries.

\section{Research methodology and purpose of the study}

The method used in the research presented in this article was the thematic content analysis. Both quantitative and qualitative analysis procedures were used (Mayring 2000; Anderson 2007; Vaismoradi, Turunen and Bondas 2013; Altheide and Schneider 2013).

The research objectives pursued in the present work were, on the one hand, to identify the covered topics on food and nutrition and to set up of the main characteristics of the media coverage of the topic, and on the other hand to highlight the similarities and differences between Romanian and German media, both in terms of the topics covered and the content of the articles, as well as in the aspects of media coverage. As regards the main traits of mass media, we were interested, among others, in which types of media in the two countries articles on nutrition have published more frequently, and in which kind of articles this topic was approached. When it comes to the media topics and the content of the articles analyzed, this paper discusses the results of the research regarding the most common topics and sub-issues having a connection with nutrition addressed by journalists, the extent to which food was presented in articles and, more precisely, what types of foods, as well as the extent to which the articles have approached different controversial issues related to nutrition. 
To collect the data for the content analysis, we used an analysis grid that was common for the research made in all countries included in the project. The time period and sampling procedures of the articles were also common for both countries, the only difference being the search keyword used for the articles' selection. Due to the fact that the articles analyzed were published in the national language (of each country included in the study), the search keyword in each country was the term in the national language which was more closely related to the phenomenon of "food / nutrition". Thus, for the analysis in Romania the term used for the selection of articles was "Alimentație", while for the analysis in Germany it was "Ernährung". Both terms mentioned, in Romanian and in German, used as search keywords, correspond to the term "nutrition" in English.

The sampling procedure for the articles included in the analysis involved the following steps: a) in the online search engine www.google.com we used the words mentioned ("Alimentatiie" for the analysis in Romania and "Ernährung" for the analysis in Germany); b) in the Google menu, we chose "News" and from "Tools" we selected "Recent", in order to narrow the time period; this was established by selecting "Custom Interval" and then filtering the time range to January 1st, 2014 - January 1st, 2017. The articles from the first ten pages of Google search were included in the analysis. Typically, ten search results (ten articles on the searched theme) appear on a Google search page (Choi and Varian 2011). However, when searching for German online media, in some cases, more than one press article was displayed for a particular topic. As a result, the analysis corpus in the German research consisted of more than one hundred articles, more precisely of 138 articles, because that many results were displayed on the first ten Google search pages. In the case of research in Romania, on the other hand, the analysis corpus consisted of less than 100 articles, namely 80, because on the first ten pages of Google search less than one hundred articles on food/nutrition have appeared. All Google results displayed, which were taken into consideration in the analysis, were online press articles and news in Romanian language and, respectively, in German language. 
The analysis grid, which was common to both countries, had 45 items, each with a number of categories that ranged from 2 to 33 . Depending on the unit of analysis, the categories were either exclusive, so with only one possible category to choose, as in the case of items related to the type of media and the type of articles, or multiple, as in the case of items related to the topic of the article, the foods presented in the articles, the addressed controversial issues etc.

\section{Results and discussions}

A first difference regarding to the media coverage of nutrition in Romania and Germany during the mentioned period of time is related to the type of media where the articles with such a topic were published. While, in the Romanian media, most articles which covered the topic of nutrition and food (71\% of the total) were published on television stations websites and aggregated websites, more precisely, on websites containing not just news, but also various other information, in the German media most articles about food and nutrition were published in newspapers (in their online format) and on the news websites (a total of $65 \%$ of the German articles analyzed were published by such media).

Table 1. Types of media which published articles about food/nutrition during 20142016 period

\begin{tabular}{|c|c|c|c|c|}
\hline \multicolumn{5}{|c|}{ Types of media } \\
\hline & \multicolumn{2}{|c|}{ Romania $\left(\mathrm{n}_{\mathrm{R}_{0}}=80\right)$} & \multicolumn{2}{|c|}{ Germany $\left(\mathrm{n}_{\text {Ger }}=138\right)$} \\
\hline & $\begin{array}{l}\text { No. of articles } \\
\text { published in/ by: }\end{array}$ & $\%$ & $\begin{array}{l}\text { No. of articles } \\
\text { published in/ by: }\end{array}$ & $\%$ \\
\hline Newspapers & 7 & 9 & 52 & 38 \\
\hline Magazines & 15 & 19 & 31 & 22 \\
\hline TV stations websites & 30 & 37 & 5 & 4 \\
\hline Radio websites & - & - & 4 & 3 \\
\hline News websites & 1 & 1 & 37 & 27 \\
\hline Aggregate websites & 27 & 34 & 2 & 1 \\
\hline News agencies & - & - & 1 & 1 \\
\hline $\begin{array}{l}\text { Online specialized platforms/ portals } \\
\text { (in nutrition, medicine, law etc.) }\end{array}$ & - & - & 6 & 4 \\
\hline Total & 80 & 100 & 138 & 100 \\
\hline
\end{tabular}


In a relatively similar percentage, in both countries, magazines published articles on nutrition (see Table 1). However, in Germany some articles on this topic ( $8 \%$ of the total) were published by certain types of media which have not been used in Romania during the three years period for such purpose. This was the case of the radio stations websites, the specialized websites or online platforms (in the field of nutrition, medicine or law) and the news agencies.

Most articles covering nutrition, both in Romania (57\%) and in Germany $(41 \%)$, were analysis articles, that is, articles that offered a more detailed approach to the subject, analyses and sometimes journalists' points of view. Some differences between media in the two countries could be stated in other journalistic genres used, as follows: in Germany, on the second place in the hierarchy of articles that covered food issues were the reportages (23\% of total articles), that is, the type of articles in which a particular topic or event, related to the investigated theme, is reported and analyzed, sometimes "on the spot", a journalistic genre which was seldom found in Romanian online media's coverage of this issue (only in 3\% of articles). In contrast, in Romania we encountered more review articles than in Germany $(20 \%$ versus $13 \%)$, that is, the type of articles which offered a retrospective or recapitulative perspective on a topic related to nutrition, or summarized the current state of knowledge or understanding of the subject, with the aim to obtain the attention of the general public.

As can be seen in Table 2, in Romania there were more interviews than in Germany (6\% versus $4 \%$ ). Moreover, the topic of interest was in Romania also approached in the texts of some television programs ( $8 \%$ of the total Romanian articles analyzed), while in Germany there was no such article. On the other hand, in the German online media we have found more overview articles (9\%, compared to $3 \%$ in Romania), that is, the type of journalistic genre that combines the synthesized content of several specialized articles in an article which has a broader aim, and more simple news (6\%, compared to 3\% in Romania), that is, those news in which the topic of nutrition was presented or reported, usually in brief, without further analysis. Also, in Germany there 
have been also more opinion articles (4\%), which did not exist in the Romanian media which covered the topic, that is, the type of articles in which the journalist presents his or her reflections and a well-defined personal opinion.

Table 2. Types of articles that addressed the nutrition topic during 2014-2016 period

\begin{tabular}{|l|c|c|c|c|}
\hline \multicolumn{5}{|c|}{ Types of articles } \\
\hline & \multicolumn{2}{|c|}{ Romania $\left(\mathrm{n}_{\mathrm{Ro}}=80\right)$} & \multicolumn{2}{c|}{ Germany(n $\left.\mathrm{nce}^{-}=138\right)$} \\
\cline { 2 - 5 } & No. & $\%$ & No. & $\%$ \\
\hline Analysis articles & 46 & 57 & 56 & 41 \\
\hline Reportages & 2 & 3 & 32 & 23 \\
\hline Review articles & 16 & 20 & 18 & 13 \\
\hline Overview/ opening articles & 2 & 3 & 13 & 9 \\
\hline Simple news & 2 & 3 & 8 & 6 \\
\hline Opinion articles & - & - & 6 & 4 \\
\hline Interviews & 5 & 6 & 5 & 4 \\
\hline Texts of TV programs & 7 & 8 & - & - \\
\hline Total & 80 & 100 & 138 & 100 \\
\hline
\end{tabular}

Due to the fact that the key word used for articles' selection was "nutrition", the topic of nutrition was present in one form or another in all articles included in the sample (see Table 3). For most of them, this was the main topic, both in Romania (91\% of the total) and in Germany (88\% of the total). In the same proportion (9\%) nutrition was a secondary theme related to the main theme (e.g. health, different diseases, lifestyle, habits etc.) in both countries. Only in three of the articles resulting from the selection in the German media (i.e. 2\% of the total of 138 articles) nutrition was mentioned only briefly. These three articles were not considered for the subsequent categories of analysis, so the further analysis corpus for Germany ( $\mathrm{n}_{\mathrm{Ger}}$, for the items that followed, was of 135 articles.

Table 3. Nutrition as the main/ secondary topic of articles

\begin{tabular}{|l|c|c|c|c|}
\hline \multicolumn{5}{|c|}{ Nutrition/ food was: } \\
\hline & Romania (n $\left.{ }_{\text {Ro }}=80\right)$ & \multicolumn{2}{c|}{ Germany (nGer $=138$ ) } \\
\hline & No. & $\%$ & No. & $\%$ \\
\hline The main topic of the article & 73 & 91 & 122 & 88 \\
\hline $\begin{array}{l}\text { Secondary theme (related to the main theme) of the } \\
\text { article }\end{array}$ & 7 & 9 & 13 & 9 \\
\hline Only briefly mentioned in the article & - & - & 3 & 2 \\
\hline Total & 80 & 100 & 138 & 100 \\
\hline
\end{tabular}


Regarding the content of the articles about food/nutrition in the media of the two countries during the period 2014-2016, we have analyzed, on the one hand, the topics of the articles (whether it was the main topic or related to the main topic), as well as the extent to which certain issues or specific aspects of interest concerning alimentation have been presented or mentioned in the articles. On the other hand, we investigated also the extent to which in the text of the articles a form or another of food was covered, the categories of foods most commonly covered, as well as the extent to which dietetic or nondietetic foods were presented.

As can be seen in Table 4, most of the articles analyzed, both in Romania and in Germany, had nutrition as a general topic. This first observation is highlighted mainly by the research data from Germany, where 125 out of a total of 135 articles had nutrition as one of the central topics. In the case of Romanian articles, nutrition was, most frequently, the general topic of the articles, although in a lesser extent than in Germany (42 Romanian articles out of a total of 80 dealt with this topic). Between 2014 and 2016 other important topics in German online media were, in hierarchical order: the risks associated with alimentation and foods, diets, diseases related to nutrition and food, eating and food in connection with a particular disease or condition, food (in general or a particular product), sustainability of food production, large businesses in the food industry and so on. Apart from the last two mentioned topics, which have never been covered (large businesses in the food industry) or only rarely (the sustainability of food production) in the case of Romanian articles, the other topics listed above were the most common also in Romania, although in a different order.

A difference between the topics covered in the two countries in relation to food is represented by the presence in German media (although not in a considerable number, but still a significant one), in addition to the topic of food production sustainability, of other issues of interest, such as: deforestation/drought/ soil erosion and other environmental problems (although these phenomena are currently major social and environmental problems also in Romania, they have not been the subject of any article in 
three years); global warming and climate change in relation to food production; pollution; agricultural crops (in general or a certain one); national policies on healthy eating and food; national standards in nutrition and food labels, the livestock industry etc. Such subjects were either not covered at all in the articles in Romania or were mentioned and presented only sporadically.

Table 4. The topic of articles analyzed

\begin{tabular}{|c|c|c|c|}
\hline & The topic of articles & $\begin{array}{c}\text { Romania } \\
\mathrm{n}_{\mathrm{R}_{0}}=\mathbf{8 0}\end{array}$ & $\begin{array}{l}\text { Germany } \\
\mathrm{n}_{\mathrm{Ger}}=135\end{array}$ \\
\hline 1 & Nutrition & 42 & 125 \\
\hline 2 & Risks associated with nutrition and food & 21 & 74 \\
\hline 3 & Diets (in general or a certain one) & 26 & 68 \\
\hline 4 & Diseases associated with food/nutrition & 26 & 63 \\
\hline 5 & Nutrition and food related to a specific disease or illness & 38 & 46 \\
\hline 6 & Food (in general or a specific product) & 21 & 43 \\
\hline 7 & Sustainability of food production & 1 & 15 \\
\hline 8 & Big business in food industry & 0 & 11 \\
\hline 9 & Deforestation/ drought/ soil erosion and/or other environmental issues & 0 & 9 \\
\hline 10 & National policies related to healthy nutrition and food & 1 & 8 \\
\hline 11 & Junk-food & 8 & 7 \\
\hline 12 & National standards and labels in nutrition and foods & 1 & 6 \\
\hline 13 & Global warming/ climate changes related to food production & 0 & 5 \\
\hline 14 & Crops (in general or a specific crop) & 0 & 5 \\
\hline 15 & Pollution & 1 & 4 \\
\hline 16 & National food patrimony & 4 & 4 \\
\hline 17 & Animal industry & 1 & 4 \\
\hline 18 & Quantity of food & 14 & 3 \\
\hline 19 & International/ European policies related to healthy nutrition and food & 1 & 3 \\
\hline 20 & Genetic modified organisms & 3 & 3 \\
\hline 21 & Organic cultures/ crops & 5 & 2 \\
\hline 22 & Consumer rights related to food & 0 & 2 \\
\hline 23 & Humanitarian and/or famine crisis related to food and nutrition & 1 & 2 \\
\hline 24 & National legal system related to healthy nutrition and food & 0 & 2 \\
\hline 25 & Bio- and nanotechnologies related to food & 0 & 2 \\
\hline 26 & Local communities' risks and benefits related to food and nutrition & 1 & 2 \\
\hline 27 & $\begin{array}{l}\text { Animal-related diseases (Avian influenza, Blue tongue disease, } \\
\text { Salmonella etc.) }\end{array}$ & 0 & 2 \\
\hline 28 & International/ European standards and labels in nutrition and food & 0 & 1 \\
\hline 29 & Biodiversity risks and benefits & 0 & 1 \\
\hline 30 & $\begin{array}{l}\text { Nutrition and food related to specific national and/or religious celebrations/ } \\
\text { feasts }\end{array}$ & 4 & 1 \\
\hline 31 & Pesticides and herbicides & 1 & 0 \\
\hline 32 & Taxes related to junk-food/alcohol/ tobacco & 0 & 0 \\
\hline 33 & International/ European legal system related to healthy nutrition and food & 0 & 0 \\
\hline
\end{tabular}

Some subjects were however more often addressed by the Romanian media than by the German one, such as the quantity of food (that is, the available quantities of food at which the reference was made), the topics related to food and eating in connection with certain specific holidays, 
national or religious, as well as those related to organic crops. It is worth noticing that neither the German nor the Romanian media addressed topics related to taxes on junk-food/ alcohol/ tobacco or to the international/ European legal system on nutrition and healthy food during the three years considered.

In addition to analysing these themes, which constituted the main or secondary topics of the articles, we were also interested in the presence or absence in Romanian and German articles of relevant issues and aspects regarding nutrition and/or food, without them necessarily being the main theme of the article. The results of our research in the Romanian and German media during the considered time frame are presented in Table 5.

As can be seen in Table 5, the three most common types of issues and aspects present in the content of articles about nutrition and food are the same both in Romania and in Germany, namely: the role of nutrition in relation to health (mentioned in $86 \%$ of the Romanian articles and $76 \%$ of the German ones), the nutritional value of the food (highlighted in $75 \%$ of the Romanian articles and $66 \%$ of the German ones), and also various educational and informative aspects regarding food and nutrition (present in 59\% of Romanian articles and $61 \%$ of German ones). The following places in the hierarchy of issues or aspects mentioned in the two countries are different. In the fourth place of the Romanian media hierarchy, food quality standards are mentioned ( $44 \%$ of the Romanian articles indicate them, while in the German media they appear only in $20 \%$ of the articles), while in the German media there are mentions about the role of the consumer in relation to food and nutrition (present in $43 \%$ of German articles and only $21 \%$ of Romanian ones).

Other nutritional issues or aspects mentioned relatively frequently and similarly in the online media from both countries refer to: various marketing and communication elements about food (present in $26 \%$ of Romanian articles and $22 \%$ of German ones); popular myths and beliefs regarding nutrition and food (mentioned in $21 \%$ of Romanian articles and 19\% of German ones); aspects regarding modern versus traditional life (pointed out in $20 \%$ of 
Romanian articles and 19\% of German ones); the role of the food industry (highlighted in $16 \%$ of Romanian articles and $11 \%$ of German ones).

Table 5. Specific issues covered or mentioned in the articles analyzed

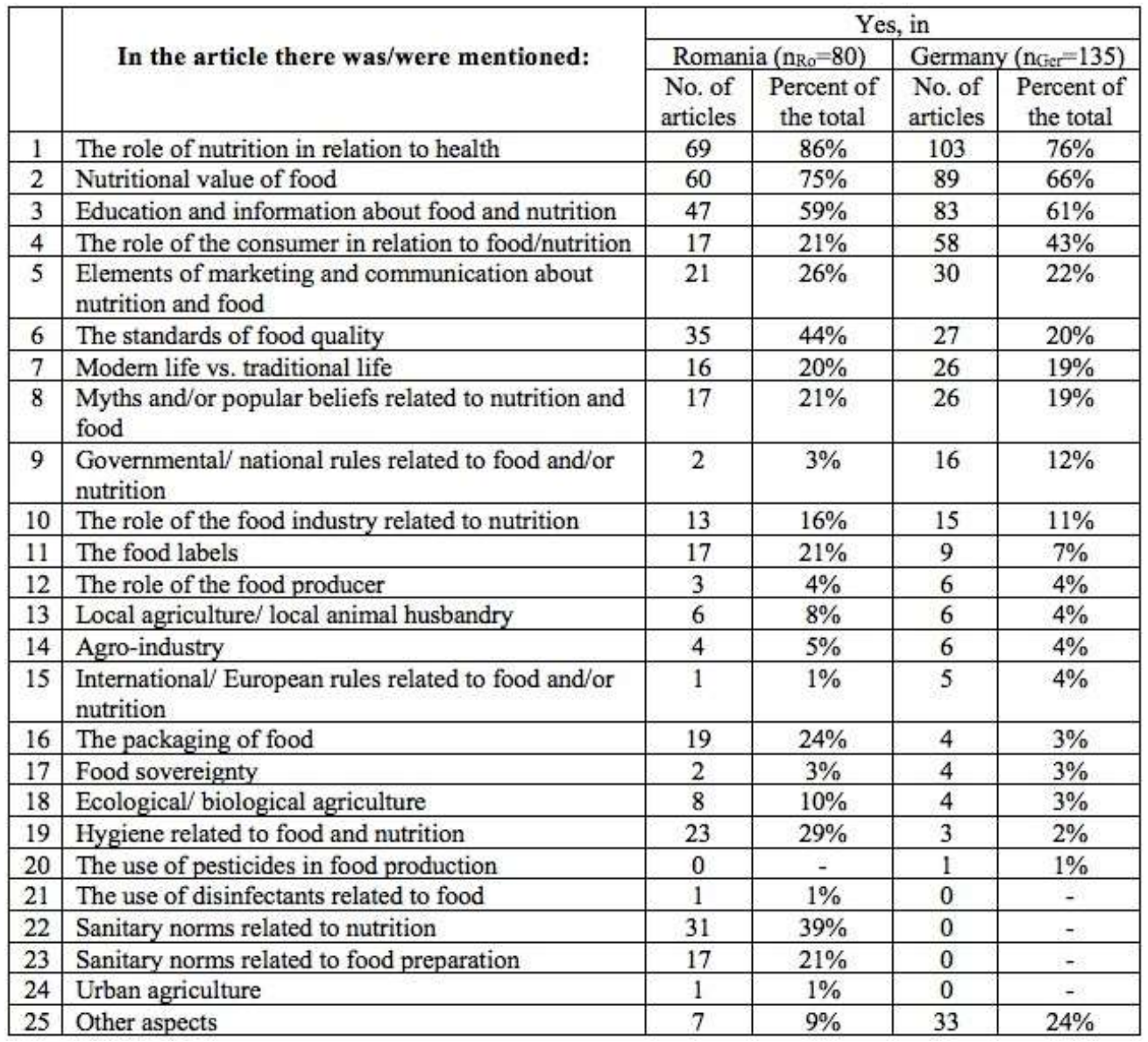

It is worth mentioning that there could be also identified several major differences between the media interests in the two countries regarding the topic of nutrition. While the German media was rather concerned with the governmental/ national rules related to food and nutrition, $12 \%$ of the German articles mentioning them (in the Romanian media such norms appeared in only $3 \%$ of the articles), Romanian media has been deeply concerned with issues and topics of little or no relevance to the German media, namely: sanitary norms and standards in connection with nutrition 
(mentioned in no less than 39\% of Romanian articles, but never in German ones), sanitary norms related to food preparation (covered in $21 \%$ of Romanian articles, but never in German ones); hygiene related to food and nutrition (subject mentioned in $29 \%$ of Romanian articles, but only in $2 \%$ of German ones), as well as food packaging (discussed in $24 \%$ of Romanian articles, but only in 3\% of German ones).

Regarding the presence of foods in the articles, the situation in the online media from Romania and Germany is similar, as shown in Table 6: aliments were present in $91 \%$ of Romanian articles as well as in $91 \%$ of German articles.

Table 6. The presence of foods in the articles analyzed

\begin{tabular}{|l|c|c|c|c|}
\hline \multirow{2}{*}{$\begin{array}{c}\text { Foods/ aliments were mentioned in } \\
\text { the article }\end{array}$} & \multicolumn{2}{|c|}{ Romania $\left(\mathrm{n}_{\mathrm{Ro}}=80\right)$} & \multicolumn{2}{|c|}{ Germany (nGer $=135)$} \\
\cline { 2 - 5 } & $\begin{array}{c}\text { No. of } \\
\text { articles }\end{array}$ & $\begin{array}{c}\text { Percent of the } \\
\text { total }\end{array}$ & $\begin{array}{c}\text { No. of } \\
\text { articles }\end{array}$ & $\begin{array}{c}\text { Percent of the } \\
\text { total }\end{array}$ \\
\hline Yes & 73 & $91 \%$ & 123 & $91 \%$ \\
\hline No & 7 & $9 \%$ & 12 & $9 \%$ \\
\hline All articles & 80 & $100 \%$ & 135 & $100 \%$ \\
\hline
\end{tabular}

We were further interested in what types of foods were most commonly media covered in both countries. A first analysis classification was determined by the presence of dietetic or non-dietetic foods in the articles. The results regarding this item are illustrated in Figure 1 (for the Romanian media) and Figure 2 (for the German media).

Figure 1. Categories of foods present in articles related to nutrition in Romania

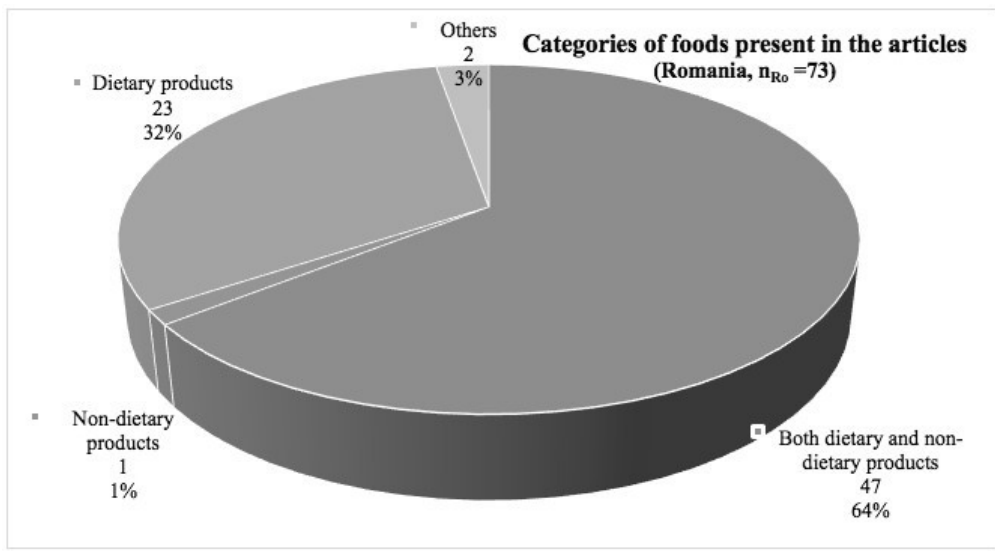


Figure 2. Categories of foods present in articles related to nutrition in Germany

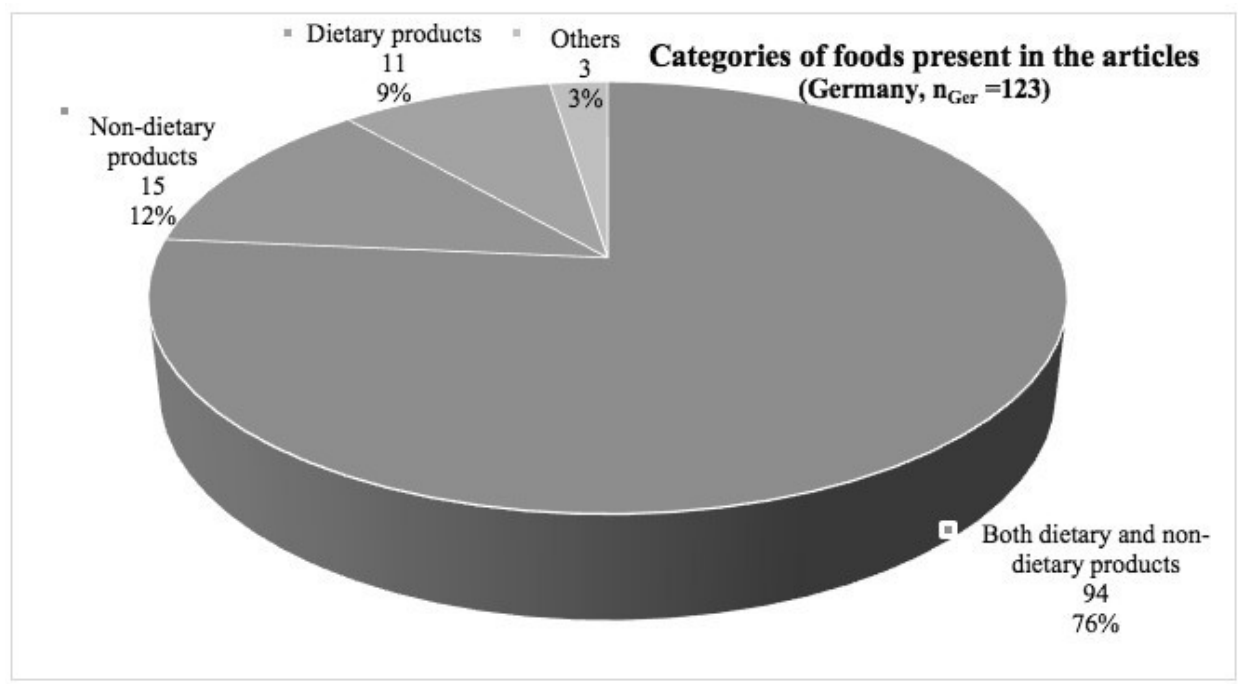

Certain categories of foods were covered in 73 articles from the total of 80 Romanian articles, and in 123 articles from the total of 135 German articles. Both in Romania and Germany, the articles related to nutrition analyzed covered or mentioned most frequently both dietary and non-dietary products (this was the case of $76 \%$ of German articles and $64 \%$ of Romanian ones). The media in the both countries differ, however, in terms of exclusively publishing information on dietetic and non-dietetic products. In Germany, in the 20142016 period, there were articles in approximately similar proportions that covered only dietetic products, respectively only non-dietetic products (the latter being even more present: $12 \%$ of cases, as compared to $9 \%$ represented by the articles in which dietetic products appeared exclusively), whereas in Romania, the articles in which only dietetic food products were covered clearly prevailed $(32 \%$ of cases, compared to only $1 \%$ as represented by articles that referred exclusively to non-dietetic products). In $3 \%$ of the articles, both in Germany and Romania, the presented products could not be classified according to the criterion "dietetic" or "non-dietetic".

Figure 3 shows the categories of dietary foods present in the considered time period in Romanian and German articles. In order to have a comparative perspective, we calculated percentages for each food product, with reference to the total number of articles in each country in which dietary products were 
mentioned (70 in the Romanian media and 105 in the German media). Thus, the graph shows percentages per line, for each type of dietary food, the percentages being related to the total number of items in each country who were referring dietetic aliments (70, respectively 105).

Figure 3. Categories of dietary foods and products present in the articles analyzed

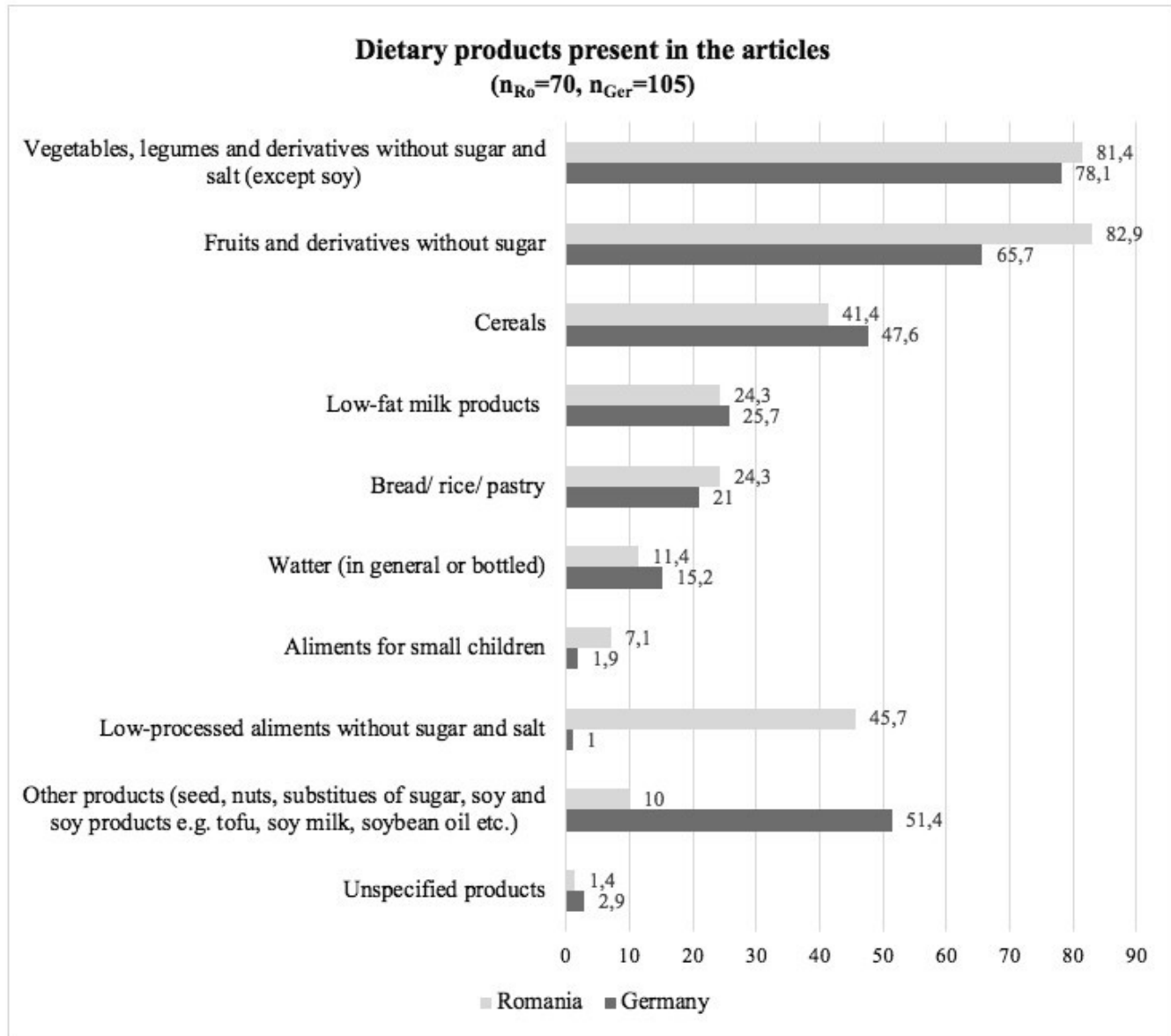

As can be seen in the chart, the most covered dietetic products both in Romania and in Germany were vegetables, legumes and their derivatives with no sugar or salt (except for soy, which was considered separately, in the category "other products"), these being mentioned in 57 out of 70 articles who covered dietetic aliments in Romania (i.e. in $81,4 \%$ of these articles), and in 82 out of 105 articles that covered dietetic foods in Germany (i.e. in 78,1\% of these 
items), respectively fruits and their sugar-free derivatives, covered in 58 of the total of 70 Romanian articles in which dietetic products were present (i.e. in $82,9 \%$ of these items) and in 69 articles out of 105 German articles who referred dietary aliments (i.e. in $65,7 \%$ of them).

In German media, out of 105 articles discussing dietetic foods, 54 (i.e. $51,4 \%$ ) mentioned seed, nuts, sugar substitutes, soy and soy products such as tofu, soy milk, soybean oil, etc. (illustrated in Figure 3 in the category "other products"). Such products were rarer mentioned in Romanian media (only in seven articles out of 70 , i.e. in $10 \%$ of them). In contrast, in $45,7 \%$ of the Romanian articles mentioning dietary products, low-processed foods without sugar and salt were frequently discussed (in 32 articles out of 70). According to our research, such aliments were not a topic of interest to the German media (only one article out of 105 mentioned such foods, i.e. less than 1\%).

Other categories of dietary foods and products covered in relatively similar proportions in the German and Romanian media were: cereals (in 50 of the total of 105 German articles and in 29 of the total of 70 Romanian ones, respectively); low-fat dairy products (in 27/105 German articles and 17/70 Romanian ones); bread, rice and dietetic pastry products (in 22/105 German articles and 17/70 Romanian ones). Less commonly covered were water (regular or bottled), present in 15,2\% of the German articles and in 11,4\% of the Romanian ones), and baby food (mentioned in 7,1\% of the Romanian articles and only in 1,9\% of the German ones).

Not only dietetic, but also non-dietetic foods have been mentioned in many media articles, especially in Germany. Figure 4 shows the categories of non-dietetic aliments present in the considered time period in Romanian and German articles analyzed. As in Figure 3, the graph shows percentages per line, for each type of non-dietary food, the percentages being related to the total number of articles in each country in which non-dietary products were mentioned (in this case, 48 articles in the Romanian media, respectively 109 in the German media). 
Figure 4. Categories of non-dietary foods and products present in the articles analyzed

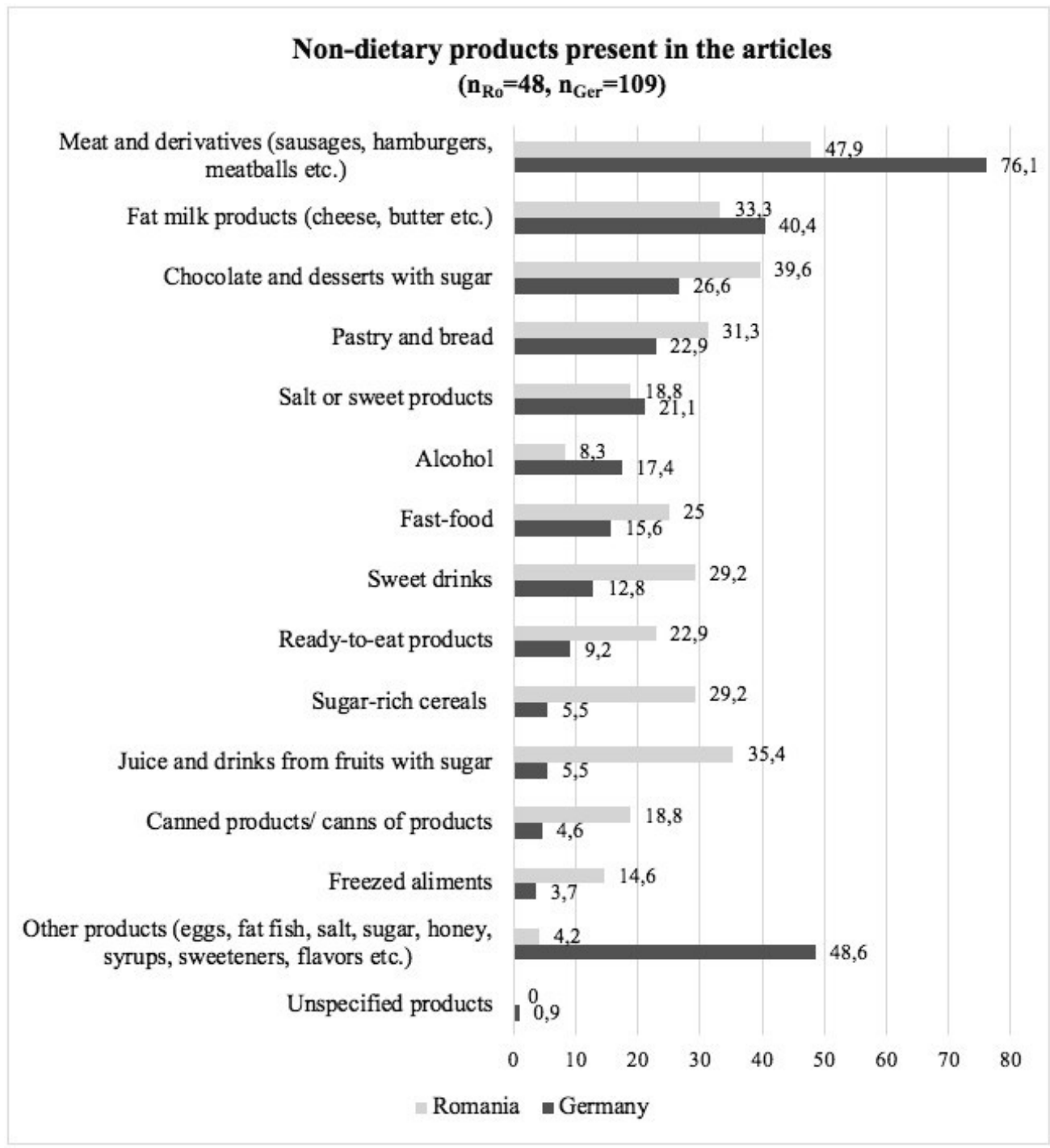

It is worth mentioning that from the total of articles analyzed in the two countries (80 in Romania and 135 in Germany), there were references to nondietary food products in much more articles in the German media (more precisely, in 109 articles, i.e. 80,7\% of the total) compared to the Romanian media (here non-dietary products were mentioned in 48 articles out of 80 , i.e. in $60 \%$ of the total). 
The most covered category of non-dietetic products was, in both countries, although in Germany to a much greater extent, the category of meat and its derivatives (sausages, hamburgers, meatballs, etc.). They were present in 83 articles out of a total of 109 German articles that mentioned non-dietetic food products (i.e. in $76,1 \%$ of cases), respectively in 23 out of a total of 48 Romanian articles that mentioned non-dietetic food products (i.e. in $47,9 \%$ of cases).

A difference between the two countries is represented by the products that are in the second and third places in the hierarchy of non-dietetic foods categories covered. Thus, in Germany, in the second place "other (nondietetic) products" were covered, which included foods such as eggs, fatty fish, salt, sugar, honey, syrups, sweeteners, flavors etc. (present in 53 out of 109 articles, i.e. in $48,6 \%$ of them), followed, in the third place, by fat dairy products (such as cheese, butter etc.), present in 44/109 German articles (representing $40,4 \%$ of the items that mentioned non-dietary foods). On the other hand, in Romania, in the second place were covered chocolate and sugary desserts (present in 19 out of a total of 48 articles, i.e. in 39,6\% of them), and in the third place, juices and sugary fruit drinks (mentioned in 17/48 Romanian articles, i.e. in $35,4 \%$ of these items).

Other significant differences between articles in Germany and Romania, regarding the media coverage of non-dietetic foods, refer to the presence, in a considerably greater extent, relative to the total of the articles that mentioned such foods in both countries, of certain products in the Romanian media compared to the ones from Germany. For example, sugar-rich cereals were present in $29,2 \%$ of the Romanian articles that recorded information on nondietetic food products, whereas in the German articles of the same type, only in 5,5\%; ready-to-eat products appeared in almost $23 \%$ of Romanian articles, but only in 9,2\% of German ones; canned and preserved products were mentioned in almost $19 \%$ of the articles in Romania and only in $4,6 \%$ of the articles in Germany; frozen foods were present in $14,6 \%$ of the Romanian articles, but only in 3,7\% of the German articles. On the other hand, the alcohol was more often present in the German media than in the Romanian one: 17,4\% 
of German articles which mentioned non-dietetic products specified also one form or another of alcohol, while only 8,3\% of Romanian articles did so.

Figure 5 shows the results of our comparative research regarding the coverage of products such as fats, nutritional supplements, spices, tea and coffee. The graph illustrates, too, percentages per line, for each type of mentioned products, and the percentages are related to the total number of articles in each country in which aliments were covered, namely 73 articles in the Romanian media and 123 articles in the German media.

Figure 5. Other food products present in the analyzed articles related to nutrition

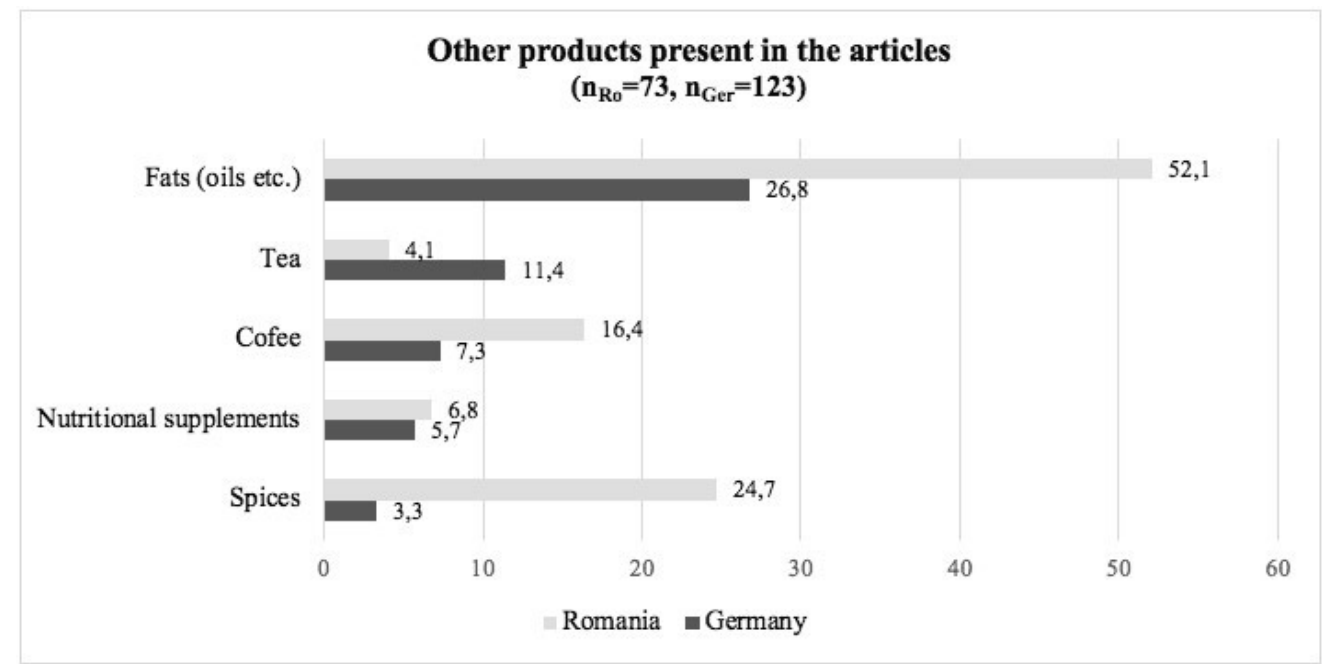

As can be seen in the chart, such products, with the exception of tea, were more often covered in the Romanian media than in the German one relative to the total number of articles in each country where food was present $\left(\mathrm{n}_{\mathrm{Ger}}=123, \mathrm{n}_{\mathrm{Ro}}=73\right)$. The clearest difference could be highlighted in the coverage of spices, which, according to our research data, were about eight times more present in Romanian articles than in German ones (more precisely, in $24,7 \%$ of Romanian articles and only in 3,3\% of German articles, relative to the total number of articles in each country where food was mentioned).

Also, fats and coffee were covered twice as much in the online media in Romania compared to Germany (fats: in about 52\% of Romanian articles, respectively in about $27 \%$ of German ones; coffee: $16,4 \%$ in Romanian articles, 
$7,3 \%$ in German ones), while the nutritional supplements were present about the same extent in the media of the two countries (almost 7\% in Romanian media, respectively almost $6 \%$ in German media). Only the tea was more frequently mentioned in the articles in Germany compared to those in Romania: about three times more often (in $11,4 \%$ of the German articles, but only in $4,1 \%$ of the Romanian ones).

Another point of interest of our study was the analysis of the extent to which controversial issues were mentioned in the articles related to food and nutrition in Romania and Germany. Table 7 illustrates the results of our comparative research regarding this item. As can be seen, the German media have more frequently covered, as compared to the Romanian media, controversial issues regarding nutrition and alimentation. More than half of the German articles (64\%) presented or at least mentioned a controversial problem, while only about $44 \%$ of the Romanian articles did so.

Table 7. The presence of controversial issues in articles analyzed

\begin{tabular}{|l|c|c|c|c|}
\hline \multirow{2}{*}{$\begin{array}{c}\text { Controversial issues/ aspects } \\
\text { were mentioned in the article }\end{array}$} & \multicolumn{2}{|c|}{ Romania $\left(\mathrm{n}_{\mathrm{R}}=80\right)$} & \multicolumn{2}{c|}{ Germany (ner $=135)$} \\
\cline { 2 - 5 } & No. of articles & $\begin{array}{c}\text { Percent of the } \\
\text { total }\end{array}$ & No. of articles & $\begin{array}{c}\text { Percent of the } \\
\text { total }\end{array}$ \\
\hline Yes & 35 & $44 \%$ & 87 & $64 \%$ \\
\hline No & 45 & $56 \%$ & 48 & $36 \%$ \\
\hline All articles & 80 & $100 \%$ & 135 & $100 \%$ \\
\hline
\end{tabular}

Moreover, we were interested in the area of the controversial issue. Table 8 illustrates the content analysis results from both countries.

Table 8. References to controversial issues addressed or mentioned in articles analyzed

\begin{tabular}{|l|c|c|}
\hline \multicolumn{3}{|c|}{ The controversial issue/ aspect in the article refers to: } \\
\hline & Romania ( $\left.\mathrm{n}_{\mathrm{Ro}}=35\right)$ & Germany (n $\left.\mathrm{n}_{\mathrm{Gir}}=87\right)$ \\
\hline Food consumers' risks and safety & 3 & 39 \\
\hline Food producers' costs and benefits & - & - \\
\hline Food industry issues & - & 9 \\
\hline Environmental issues & - & 65 \\
\hline Health-related issues & 12 & 6 \\
\hline $\begin{array}{l}\text { Economic, social and environmental sustainability of } \\
\text { food production }\end{array}$ & 3 & 18 \\
\hline Social issues & 17 & 18 \\
\hline Ethical issues & - & 10 \\
\hline Other types of controversial problems & - & 9 \\
\hline
\end{tabular}


The most controversial issues identified in the articles related to nutrition referred, both in Romania and in Germany, to issues concerning health and related aspects (maintaining health, medical conditions, diseases, etc.), and some social problems. As already mentioned, controversial issues were more frequently covered in German articles, but not only that: they were more diverse. Some issues rarely addressed in the Romanian media, such as the risks and safety of food consumers (present in only three articles analyzed), were often addressed in the German media (in 39 articles), and some problems, such as those related to the food industry, ethical issues and environmental issues, about which the German media have been discussing quite frequently, have never been debated or taken into account in the Romanian media.

Among the most common controversial issues encountered in the German media, with reference to both consumer health and the risks involved, are those regarding different diets and food styles. For example, many of the information and debates identified in the German analyzed articles referred to the benefits, but also to the health risks of giving up meat, meat products, and generally animal products (milk, eggs, etc.), in particular with regard to certain categories of population, such as children, teenagers and pregnant women. In connection with these categories of population, many articles have discussed the effects of giving up entirely meat and other devised animal products, drawing attention to the health risks of the vegan diet during growing up period, and during pregnancy. On the other hand, some articles have presented studies and arguments that recommend such a diet, which would only have beneficial effects, at least for adults. Regarding the vegetarian diet, some articles, presenting the results of some studies, revealed a possible connection between vegetarianism and the decrease of the incidence of some forms of cancer, such as colon cancer, while other studies, presented in other articles, argued, on the contrary, that vegetarians suffer more often from certain diseases, including cancer.

Other diets and regimens have also been often covered in German articles, such as the gluten-free and lactose-free diets, including the 
controversies surrounding them when adopted by healthy people, who do not suffer from gluten or lactose intolerance. These were discussed in the media not only as medical problems in relation to nutrition, but also as social and ethical problems, considering the social trends of adopting such diets, rather than their medical necessity. According to a German article, it is estimated that only $0,4 \%$ of Germany's population suffers from celiac disease (i.e. gluten intolerance); at the same time, every fourth German avoids gluten or lactose.

In the same context of social and ethical controversies, some articles in the German media have drawn attention to new, contemporary medical conditions, such as orthorexia nervosa, an eating disorder characterized by an excessive preoccupation with eating supposedly healthy food, a concern that, paradoxically, has unhealthy consequences, such as social isolation, decreased interest in other healthy human activities, loss of ability to eat in a natural, intuitive way, anxiety, obsessive-compulsive behaviours, and, in the most severe cases, malnutrition and even death. Five articles in German media reported, during the considered period, about this contemporary disorder.

In addition to controversial issues related to health, consumer risks, social and ethical issues, the German media discussed (in nine articles in the time frame of the analyse) controversial issues related to the influence - risks and damages - on the environment of certain lifestyles, especially the "Western" one, which involve certain harmful habits. Moreover, some articles made deeper connections between nutrition, lifestyle, average lifespan, incidence of certain diseases, treatments and costs involved, not only from a medical, social and economic point of view, but also in terms of affecting the environment and the planet. Although in Romania such risks for the environment also exist, not only related to food practices and habits, but also to the food production itself, and the connection between nutrition, lifestyle and environmental damage could and should also be discussed, no article in the Romanian media addressed such issues in the three years considered. 


\section{Conclusions}

According to the European Commission (2017), the monitorization of fruits and vegetable consumption (by the daily frequency of consumption and by the number of servings consumed daily) is assessed to be a way for measuring progress in adopting a healthy diet by the population. In 2017, Romania classifies last, after Bulgaria, in the ranking of European Union countries, in terms of the number of servings of fruits and vegetables consumed daily; thus, $68.8 \%$ of people did not include vegetables in their daily diet and $68.8 \%$ of people aged 15 and over did not include fruits in their daily diet (European Commission 2017). For the same year, the percentage of Germans aged 15 and over who did not include vegetables in their daily diet was significantly smaller $-45.6 \%$ - and only $39 \%$ of Germans aged 15 and over did not include fruits in their daily on a daily basis (ibid.). On the basis of the abovementioned data we can assume that, in average, Germans had a healthier diet than Romanians three years ago.

Those differences in so-called "social-determinants of healthy living" (World Health Organization 2020) were also noticed in the results of our analysis of media coverage of nutrition for the two countries. According to our comparative content analysis, the media coverage of the nutrition in the time period chosen for the study differed in many points in the media in Romania, respectively in Germany. Firstly, a number of differences could be ascertained regarding the characteristics of the coverage, more precisely the types of media and the types of articles that dealt online with the issue of nutrition. Thus, our analysis showed that most articles whose main or related theme was food and/or nutrition were published in Romania on television stations websites and on aggregate websites, while in Germany they appeared in newspapers and on news websites. Also, in Germany some articles on this topic have been published in/by certain types of media, which, in Romania, have not published any article on this subject, during the three years period. This has been the case for the websites of radio stations, specialized websites or online platforms, such as those in the nutritional, medical or legal fields, as well as news agencies. Due to the fact that the results are based on a specific 
methodology (presented in this paper) it is possible that through the use of other sampling criteria they can be partially different. Therefore, we cannot generalise the results beyond the sample used in this analysis.

A first similarity could be identified with regard to the most common types of articles that addressed the food issue. Thus, the media in both countries dealt most often with this topic in analysis articles. However, the rest of the types of articles on this topic differed in the two countries: the Romanian media favoured the presentation of the nutrition topics in review articles, interviews and texts of general television programs, while the German media covered the topic mainly in reportages and overview articles, in other words in some forms of journalistic genres, which involved either analysing the investigated topic and reporting "on the spot", or combining the synthesized content of several specialized articles in articles with a broad spectrum.

Another common corpus for the media of the two countries, highlighted by our research, was the most frequently covered topics related to food and nutrition. Both in Romania and Germany, nutrition as a general theme was the most common encountered topic of articles. Along with this, the risks associated with eating and foods, diets, diseases related to food and nutrition, alimentation in connection with a particular disease or condition, as well as food (in general or a specific food product), were frequently covered topics both in the Romanian and German media. In addition to these themes, however, there were topics favoured by the media in one country, while the media in the other country briefly covered such issues or even ignored them. For example, the Romanian media paid considerable attention to the amount of food, and to the nutrition associated with certain specific holidays, national or religious, topics only sporadically addressed in the German media. On the other hand, the German media often dealt with topics such as sustainability of food production, pollution (topics encountered, each, in just a single Romanian article), big businesses in the food industry, deforestation/ drought/ soil erosion and other environment issues associated with nutrition, 
respectively global warming and climate change in relation to food production - topics completely ignored by the Romanian media.

The most common types of problems mentioned in the content of the articles related to nutrition were similar in both German and Romanian media: the role of nutrition in relation to health, nutritional value of food, educational and informative aspects of food and nutrition, food quality standards, various marketing and communication elements about food and alimentation, the role of the consumer in relation to food and nutrition, myths and popular beliefs about nutrition and aliments, aspects of modern life versus traditional life, and the role of the food industry concerning nutrition.

On the other hand, our analysis also indicated some major differences between the media interests in the two countries regarding problems associated with the topic of nutrition. While the German media were more frequently concerned with the governmental/ national rules/ norms regarding food and/or nutrition, the Romanian media were intensely concerned with specific issues, especially related to health and hygiene rules, such as: sanitary norms regarding food and nutrition, sanitary norms concerning the preparation of food, hygiene in relation to food and nutrition, packaging of food products, and labelling of aliments.

As regards the types of foods most commonly covered, our comparative analysis revealed that both dietetic and non-dietetic products were presented in online press in both countries, with Romanian and German media differing when publishing exclusive information about dietetic, respectively nondietetic products. Thus, while in Romanian media mentioning dietary products was prevalent, in German media there were in approximately similar proportions articles that covered only dietary products, respectively only non-dietary products. Regarding the types of foods, dietetic or nondietetic, we could ascertain similarities and differences as well. Therefore, the most popular dietetic products were, both in Romania and Germany, vegetables, legumes, fruits and derivatives of all of them, without sugar or salt, and the most popular non-dietetic products were, in both countries, meat and its derivatives. On the other hand, the German media dealt more 
intensely that the Romanian ones with food products such as soy and soy products (tofu, soy milk, soybean oil, etc.), seed, nuts, sugar substitutes, while the media in Romania was more interested in baby foods and low-processed aliments without sugar and salt. As for the non-dietetic foods, Romanian articles dealt, more often than the German ones, with products such as juices and sugary fruit drinks, high-sugar cereals, "ready-to-eat" foods, canned and preserved products, respectively frozen foods, while German articles mentioned, more often than Romanian ones, issues regarding eggs, fatty fish, salt, sugar, honey, syrups, sweeteners, flavourings, high fat dairy products, respectively alcohol. Moreover, according to our content analysis, spices, coffee and fats (oils, etc.) were covered more often by media in Romania than in Germany.

Finally, another finding of our study was that the German media covered, as compared to the Romanian media, more frequently controversial or disputed issues regarding food and nutrition. Furthermore, the controversial issues addressed in the German media have targeted areas much more diverse than those published in the Romanian media. Online press in both countries mentioned controversial aspects regarding human health and social issues, the most common disputed subjects being related to diets, regimens, and nutritional and lifestyle trends. The German media, however, also addressed a number of controversial issues, which were briefly or not at all taken into consideration by the Romanian media, such as those regarding the risks and safety of consumers, issues related to the food industry, ethical issues and environmental issues.

In conclusion, through the comparative analysis of the media coverage of nutrition in Romania and Germany, we were able to find out both similarities and a number of significant differences. While the similarities are mainly related to some topics addressed, to the ways of covering them, in particular through analysis articles, as well as to some mentioned elements or interests that have been encountered in the media in both countries, the differences are rather related to the content of the articles and their in-depth analysis, which reveals not only differences of interest, nuance and approach 
between the Romanian and German media, but also contrasts in terms of journalists' involvement and the attitude of the press towards current, stringent issues or towards problems of general interest, including by selfassuming by the journalists of well-defined roles of information, tackling controversial issues, critical argumentation and even educating the public journalistic approaches identified in the German media, but not in the Romanian media.

\section{References}

Altheide, David L. and Christopher J. Schneider. 2013. Qualitative Media Analysis. Second Edition. London, New York: Sage Publications.

Anderson, Rosemarie. 2007. “Thematic Content Analysis (TCA): Descriptive Presentation of Qualitative Data."

http:/ / rosemarieanderson.com/wp-content/uploads/2014/08/

ThematicContentAnalysis.pdf

Bartlett, Christopher, Jonathan Sterne and Matthias Egger. 2002. "What is newsworthy? Longitudinal study of the reporting of medical research in two British newspapers." British Medical Journal 325: 81-84.

Basic Law for the Federal Republic of Germany. 2020. https://www.gesetzeim-internet.de/englisch_gg/englisch_gg.pdf.

Basu, Andrea J. and Elaine Hogard. 2008. "Fit for public consumption? An exploratory study of the reporting of nutrition research in UK tabloids with regard to its accuracy, and a preliminary investigation of public attitudes towards it." Public Health Nutrition 11: 1124-1131.

Benterbusch, Reinhild. 1997. Inhaltsanalyse zum Thema Ernährung in deutschen Zeitungen (1994/95). Karlsruhe: Berichte der Bundesforschungsanstalt für Ernährung BFE-R--97-02.

Borra, Susan T., Robert Earl and Edith Howard Hogan. 1998. "Paucity of nutrition and food safety 'news you can use' reveals opportunity for dietetics practitioners." Journal of American Dietetic Association, 98: 190193.

Bradley, Peri. 2016. Food, Media and Contemporary Culture: The Edible Image. Houndmills: Palgrave Macmillan.

Burkard, Marion and Huth, Karl. 2010. "Adipositas." In Ernährung und Fasten als Therapie, edited by Rainer Stange and Claus Leitzmann, 271-283. Berlin, Heidelberg: Springer Verlag. 
Burleson Mackay, Jenn. 2017. "Tabloidization." DOI: 10.1093/OBO/9780199756841-0191.

Caple Helen and Monika Bednarek. 2013. Delving into the Discourse: Approaches to News Values in Journalism Studies and Beyond. Working Paper. Oxford: The Reuters Institute for the Study of Journalism, University of Oxford.

Carrin, Guy and Chris James. 2005. "Social health insurance: key factors affecting the transition towards universal coverage." International Social Security Review 58 (1): 45-64.

Chapman, Simon. 2001. "Advocacy in public health: Roles and challenges." International Journal of Epidemiology 30: 1226-1232.

Choi, Hyunyoung and Hal Varian. 2011. Predicting the Present with Google Trends. http://people.ischool.berkeley.edu/ hal/Papers/2011/ptp. pdf.

Coleman, Renita, Esther Thorson and Lee Wilkins. 2011. "Testing the Effect of Framing and Sourcing in Health News Stories." Journal of Health Communication (0): 1-14. DOI: 10.1080/10810730.2011.561918.

Constituția României. 2020. https://www.constitutiaromaniei.ro/.

de Solier, Isabelle. 2005. "TV Dinners: Culinary Television, Education and Distinction." Continuum: Journal of Media \& Cultural Studies 19 (4): 465481.

Doboș, Cristina. 2008. "Finanțarea sistemelor de sănătate î̀ țările Uniunii Europene. România î̀ context European." Calitatea Vieții XIX (1-2): 107-123.

Edelman, Marc. 2014. "Food sovereignty: forgotten genealogies and future regulatory challenges." The Journal of Peasant Studies 41 (6): 959-978.

Edelman, Marc, Tony Weis, Amita Baviskar, Saturnino M. Borras Jr, Eric HoltGiménez, Deniz Kandiyoti and Wendy Wolford. 2014. "Introduction: critical perspectives on food sovereignty." The Journal of Peasant Studies 41 (6): 911-931.

Elmadfa, Ibrahim and Claus Leitzmann. 2015. Ernährung des Menschen. 5. Auflage. Stuttgart: Eugen Ulmer KG, utb-Band.

European Commission. 2017. "Social determinants - Public Health." https://ec.europa.eu/health/social_determinants/indicators_en.

Eurostat. 2020. "Health in the European Union - facts and figures. Healthcare expenditure statistics." https://ec.europa.eu/eurostat/statisticsexplained/index.php/Healthcare_expenditure_statistics.

Grilli, Roberto, Craig Ramsay and Silvia Minozzi. 2005. "Mass media interventions: effects on health services utilisation (review)." The Cochrane Database of Systematic Reviews 2: CD000389. 
Gross, Liza. 2009. "A broken trust: lessons from the vaccine-autism wars." PLoS Biology 7 (5): e1000114.

Hackman, Evette M. and Gaile L. Moe. 1999. "Evaluation of newspaper reports of nutrition-related research." Journal of American Dietetic Association 99: 1564-1566.

Hänsli, Barbara. 2006. "Prozess zwischen Angebot und Nachfrage: Ernahrungskommunikation aus publizistikwissenschaftlicher Perspektive." In Skandal oder Kontinuitat. Anforderungen an eine offentliche Ernahrungskommunikation, edited by Eva Barlösius and Regine Rehaag, 71-77. Berlin: Veroffentlichungsreihe der Forschungsgruppe Public Health Forschungsschwerpunkt Arbeit, Sozialstruktur und Sozialstaat Wissenschaftszentrum Berlin für Sozialforschung (WZB).

Health Consumer Powerhouse. 2016. Euro Health Consumer Index 2015 Report. Health Consumer Powerhouse Ltd. https://healthpowerhouse.com/files/EHCI_2015/EHCI_ 2015_report.pdf.

Henderson, Lesley, Jenny Kitzinger and Josephine Green. 2000. "Representing infant feeding: content analysis of British media portrayals of bottle feeding and breast feeding." British Medical Journal 321: 1196-1198.

Johnston, Josée and Shyon Baumann. 2010. Foodies: Democracy and Distinction in the Gourmet Foodscape. New York: Routledge.

Krippendorff, Klaus. 2018. Content Analysis: An Introduction to Its Methodology. Fourth Edition. Los Angeles, London, New Delhi, Singapore, Washington DC, Melbourne: Sage Publications.

Lavin, Chad. 2013. Eating Anxiety: The Perils of Food Politics. Minneapolis: University of Minnesota Press.

Leer, Jonatan and Karen Klitgaard Povlsen. 2016. Food and Media: Practices, Distinctions and Heterotopias. London: Routledge.

Len-Ríos, María E., Amanda Hinnant, Sun-A. Park, Glen T. Cameron, Cynthia M. Frisby and Youngah Lee. 2009. "Health news agenda building: Journalists' perceptions of the role of public relations." Journalism $\mathcal{E}$ Mass Communication Quarterly 86 (2): 315-331.

Lewis, Tania. 2008. "Transforming citizens? Green politics and ethical consumption on lifestyle television." Continuum: Journal of Media $\mathcal{E}$ Cultural Studies 22 (2): 227-240.

Mayring, Philipp. 2000. "Qualitative Content Analysis." Forum: Qualitative Social Research 1 (2): Art. 20. 
McIntosh, Jennifer and Susan J. Blalock. 2005. "Effects of media coverage of Women's Health Initiative study on attitudes and behavior of women receiving hormone replacement therapy." American Journal of HealthSystem Pharmacy 62 (1): 69-74.

Miller, Toby. 2007. Cultural Citizenship: Cosmopolitanism, Consumerism, and Television in a Neoliberal Age. Temple University Press.

Nagler, Rebekah H. 2014. "Adverse outcomes associated with media exposure to contradictory nutrition messages." Journal of Health Communication 19 (1): 24-40.

Nerlich, Brigitte and Nelya Koteyko. 2008. "Balancing Food Risks and Food Benefits: The Coverage of Probiotics in the UK National Press." Sociological Research Online 13 (3): 1. DOI: 10.5153/ sro.1692.

Ouellette, Laurie and James Hay. 2008. Better Living Through Reality TV. Oxford: Blackwell.

Paulussen, Steve and Raymond A. Harder. 2014. "Social media references in newspapers: Facebook, Twitter and YouTube as sources in newspaper journalism." Journalism practice 8 (5): 542-551.

Philo, Greg, Jenny Secker, Steve Platt, Lesley Henderson, Greg McLaughlin and Jocelyn Burnside. 1994. "The impact of the mass media on public images of mental illness: media content and audience belief." Health Education Journal 53 (3): 271-281.

Popescu, Marina, Adriana Mihai and Adina Marincea. 2016. The Media Pluralism Monitor (MPM): Romania. Centre for Media Pluralism and Media Freedom (CMPF) at the European University Institute. https:/ / cmpf.eui.eu/media-pluralism-monitor/mpm-2016results/romania/.

Raisborough, Jayne. 2016. Fat Bodies, Health and the Media. London: Palgrave Macmillan.

Reporters without Borders. 2020. "2020 World Press Freedom Index." https://rsf.org/en/world-press-freedom-index.

Roberts, Marilyn, Wayne Wanta and Tzong-Horng (Dustin) Dzwo. 2002. "Agenda setting and issue salience online." Communication Research 29 (4): 452-465.

Rousseau, Signe. 2012. Food Media: Celebrity Chefs and the Politics of Everyday Interference. Berg Publishers.

Rössler, Patrick. 2006. "Ernährung im (Zerr-)Spiegel der Medienberichterstattung? Einige Bur Ernahrungskommunikation aus kommunikationswissenschaftlicher Sicht." In Skandal oder Kontinuitait. Anforderungen an eine offentliche Ernahrungskommunikation, edited by Eva Barlösius and Regine Rehaag, 
61-70. Berlin: Veroffentlichungsreihe der Forschungsgruppe Public Health Forschungsschwerpunkt Arbeit, Sozialstruktur und Sozialstaat Wissenschaftszentrum Berlin für Sozialforschung (WZB).

Scherer Helmut and Elena Link. 2017. "Gesundheitsthemen in den Medien." In Handbuch Gesundheitskommunikation, edited by Constanze Rossmann and Matthias R. Hastall, 1-12. Wiesbaden: Springer Reference Sozialwissenschaften, Springer VS.

Schroeder, Hermann-Dieter and Kevin Dankert. 2016. The Media Pluralism Monitor (MPM): Germany. Centre for Media Pluralism and Media Freedom (CMPF) at the European University Institute. https://cmpf.eui.eu/media-pluralism-monitor/mpm-2016results/germany/.

Schulz, Wolfgang, Thorsten Held, Stephan Dreyer and Thilo Wind. 2008. Regulation of Broadcasting and Internet Services in Germany. A Brief Overview. 2nd Edition. Hamburg: Hans Bredow Institute for Media Research at the University of Hamburg.

Schwitzer, Gary. 2008. "How do US journalists cover treatments, tests, products, and procedures? An evaluation of 500 stories." PLoS Medicine 5 (5): e95.

Sihota, Saranjit and Linda Lennard. 2004. Health Literacy: Being Able to Make the Most of Health: National Consumer Council.

Stryker, Jo Ellen. 2002. "Reporting medical information: Effects of press releases and newsworthiness on medical journal articles' visibility in the news media." Preventive Medicine 35 (5): 519-530.

The Commonwealth Fund. 2013. International Profiles of Health Care Systems, 2013. Australia, Canada, Denmark, England, France, Germany, Italy, Japan, the Netherlands, New Zealand, Norway, Sweden, Switzerland, and the United States.

http://www.commonwealthfund.org/ /media/Files/Publications/ Fund\%20Report/2013/Nov/1717_Thomson_intl_profiles_hlt_care_s ys_2013_v2.pdf.

The Henry J. Kaiser Family Foundation. 2005. Public Opinion Snapshot on Health Information Sources - July 2005. http://kff.org/other/pollfinding/public-opinion-snapshot-on-health-information-sources/.

United Nations, Department of Economic and Social Affairs. 2019. World Population Prospects 2019. Volume I: Comprehensive Tables. New York: United Nations. https://population.un.org/wpp/Publications/Files/WPP2019_Volu me-I_Comprehensive-Tables.pdf. 
Vaismoradi, Mojtaba, Hannele Turunen and Terese Bondas. 2013. "Content analysis and thematic analysis: Implications for conducting a qualitative descriptive study." Nursing and Health Sciences, 15: 398-405.

Vlădescu, Cristian, Silvia Gabriela Scîntee, Victor Olsavszky, Cristina Hernández-Quevedo and Anna Sagan. 2016. "Romania: Health system review." Health Systems in Transition 18 (4): 1-170.

Wilkinson, Richard G. and Michael Marmot. 2003. Social Determinants of Health: The Solid Facts. World Health Organization.

Wittman, Hannah. 2011. "Food sovereignty: A New Rights Framework for Food and Nature?" Environment and Society: Advances in Research 2: 87105.

Woods, Michael. 2012. "Rural Geography III: Rural Futures and the Future of Rural Geography." Progress in Human Geography 36 (1): 125-134.

World Health Organization. 2020. Healthy Diet. https://www.who.int/newsroom/fact-sheets/detail/healthy-diet. 